\title{
Uterine focal adhesions are retained at implantation after rat ovarian hyperstimulation
}

\author{
Laura A Lindsay, Samson N Dowland and Christopher R Murphy \\ School of Medical Sciences (Anatomy and Histology), The University of Sydney, Sydney, New South Wales, Australia \\ Correspondence should be addressed to L A Lindsay; Email: laural@anatomy.usyd.edu.au
}

\begin{abstract}
Controlled ovarian hyperstimulation is an essential component of IVF techniques to ensure proliferation and development of multiple ovarian follicles, but the effects of these hormones on the endometrium are largely unknown. During normal pregnancy in rats, there are significant changes in the basal plasma membrane of uterine epithelial cells (UECs) at the time of receptivity, including loss of focal adhesions. This enables the UECs to be removed from the implantation chamber surrounding the blastocyst, thus allowing invasion into the underlying stroma. This study investigated the influence of ovarian hyperstimulation $(\mathrm{OH})$ on the basal plasma membrane of UECs during early pregnancy in the rat. Immunofluorescence results demonstrate the presence of paxillin, talin, integrin $\beta 1$ and phosphorylated FAK (Y397FAK) in the basal portion of UECs at the time of implantation in OH pregnancy. TEM analysis demonstrated a flattened basal lamina and the presence of focal adhesions on the basal surface at this time in $\mathrm{OH}$ pregnancy. Significantly low full-length paxillin, high paxillin $\delta$ and integrin $\beta 1$ were seen at the time of implantation in $\mathrm{OH}$ compared with those in normal pregnancy. The increase in paxillin $\delta$ suggests that these cells are less mobile, whereas the increase in integrin $\beta 1$ and Y397FAK suggests the retention of a stable FA complex. Taken together with the increase in morphological focal adhesions, this represents a cell type that is stable and less easily removed for blastocyst implantation. This may be one mechanism explaining lower implantation rates after fresh embryo transfers compared with frozen cycles.

Reproduction (2016) 152 753-763
\end{abstract}

\section{Introduction}

An essential part of the ability of uterine epithelial cells (UECs) to become receptive to an implanting blastocyst is the changes in all membrane domains of the cell, including the basal plasma membrane (Shion \& Murphy 1995). In species that have displacement penetration such as rodents and humans (Schlafke \& Enders 1975), the UECs must be removed for the implanting blastocyst to invade the underlying stroma. This removal was thought to be mediated via apoptotic mechanisms (Parr et al. 1987); however, recent evidence suggests that luminal UECs surrounding the implanting blastocyst undergo entosis ( $\mathrm{Li}$ et al. 2015). Regardless of the mode of removal of UECs, it is necessary for the UECs to become less adherent to the underlying basal lamina, and then the UECs in the region immediately surrounding the implantation chamber are removed. Previous studies in rat UECs during early pregnancy and in response to ovarian hormones showed that at the time of implantation and in response to progesterone, the basal lamina thickens, becomes highly tortuous and loses focal adhesions (Shion \& Murphy 1995, Kaneko et al. 2008).
Focal adhesions (FAs) are key structural elements that play a role in cell-matrix adhesion. These specialised structures consist of several proteins that connect the actin cytoskeleton to the extracellular matrix (ECM). Intracellular proteins associated with FAs include actopaxin, vinculin, paxillin and talin (Turner 2000) and membrane-bound integrins, which span the plasma membrane and make contact with the ECM of the basal lamina (Vuori 1998, Brown \& Turner 2004) and all of which have complex interactions (Zaidel-Bar et al. 2007, Kuo et al. 2011).

Paxillin is a linker protein that connects to integrins via focal adhesion kinase (FAK) and actin stress fibres via actopaxin and vinculin (Turner et al. 1990, Turner 2000, Schaller 2001). There are four different isoforms of paxillin with paxillin $\alpha$ being the most widely expressed (Mazaki etal. 1997, Schaller 2001, Brown \& Turner 2004). Paxillin $\delta$ is an internal translation product of paxillin $\alpha$ that is found only in epithelial cells (Brown \& Turner 2004, Tumbarello et al. 2005), and when overexpressed, leads to the inhibition of cell migration (Sorenson \& Sheibani 1999, Tumbarello et al. 2005). Talin is another intracellular protein associated with FAs and provides a direct link between the cytoplasmic domain of integrin 
and intracellular actin fibres (Nayal et al. 2004). Talin is also involved in integrin activation (Tadokoro et al. 2003), which is essential in the establishment of FAs (Yamada \& Geiger 1997, Critchley 2009).

Integrins are large membrane-spanning proteins composed of $\alpha$ and $\beta$ subunits that mediate cell-cell and cell-extracellular matrix adhesion. In vitro studies have shown that integrin $\beta 1$ and $\beta 3$ colocalise and interact with talin at FAs (Calderwood et al. 1999, Critchley 2000, Calderwood 2004). Previous studies in humans, rodents and other mammals have established that integrin $\alpha_{\vee} \beta_{3}$ is highly expressed at the time of implantation and is a well-known marker of uterine receptivity (Bowen et al. 1996, Fazleabas et al. 1997, Lessey 1997, Srinivasan et al. 2009). Integrin $\beta 1$ has previously been localised to the basal plasma membrane of rat UECs on day 1 of pregnancy and in response to oestrogen stimulation (Kaneko et al. 2011).

Focal adhesion kinase (FAK) is a cytosolic protein tyrosine kinase associated with the FA complex and is involved in many aspects of cell migration, invasion and signalling (Cary \& Guan 1999, Hauck et al. 2002). Previous work in rat UECs during early pregnancy and in response to ovarian hormones has shown that FAK is found apically at the time of implantation and in response to progesterone. This apical localisation of FAK is suggested to be involved in integrin-integrin binding between UECs and blastocyst, which is an essential part of implantation (Kaneko et al. 2012). Human studies have also shown an increase in FAK staining within the luminal and glandular UECs in the mid-secretory phase of the menstrual cycle indicating a role in human uterine remodelling and implantation (Orazizadeh et al. 2009).

For FAK to control intracellular signalling pathways, autophosphorylation must occur, and this can happen on a number of residues including tyrosine-397. This autophosphorylation then activates many of the kinasedependant functions of FAK (Katz et al. 2003, BramiCherrier et al. 2014). Specifically, phosphorylation of FAK atY397 (Y397FAK) leads to the activation of integrins in a variety of cell types in vitro and in vivo (Chan et al. 1994, Schaller et al. 1994, Eide et al. 1995, Schlaepfer et al. 1999). Although several studies have investigated FAK in the endometrium (Orazizadeh et al. 2009, Kaneko et al. 2012), currently no studies have examined the physiologically active form of FAK, Y397FAK, in the endometrium. However, in the myometrium, an increase in phosphorylation of FAK is associated with stretch-induced activation of human myometrial cells (Li et al. 2009). In human placental cytotrophoblast cells, it was found that Y397FAK, rather than overall FAK levels, is associated with invasion ability and that under conditions of hypoxia in vitro and pre-eclampsia in vivo, there was a reduction in Y397FAK (Ilić et al. 2001).

During IVF procedures, controlled ovarian hyperstimulation $(\mathrm{COH})$ is required to stimulate oocyte production and maturation. $\mathrm{COH}$ has a detrimental effect on the uterine lining, which impedes blastocyst implantation. This is confirmed in several studies that show a significant decrease in implantation rate when embryos are transferred during the $\mathrm{COH}$ cycle, compared with those transferred in subsequent cycles (Paulson et al. 1990, Check et al. 1994, 2010, Shapiro et al. 2011, 2014). However, the mechanisms underlying the effect of $\mathrm{COH}$ on uterine receptivity are currently unknown.
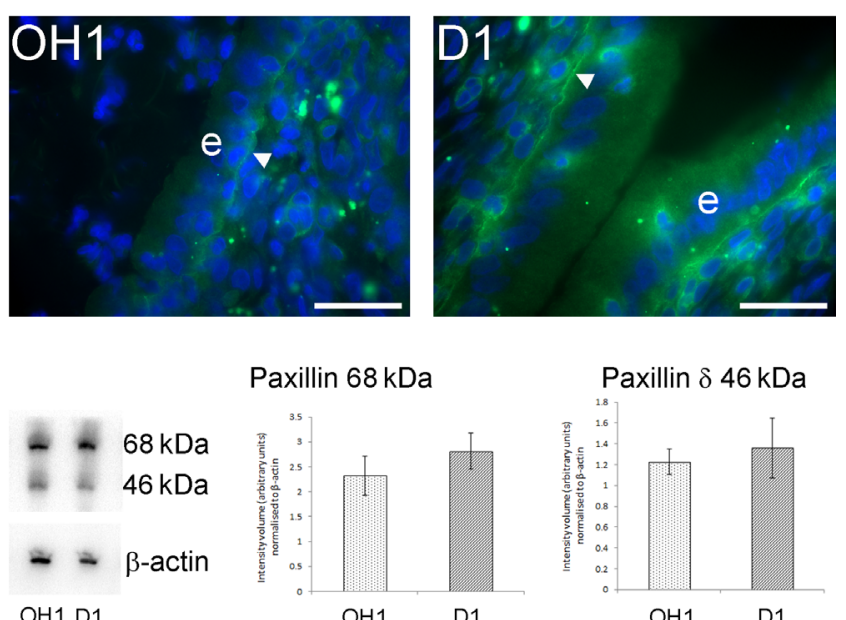

Paxillin $68 \mathrm{kDa}$
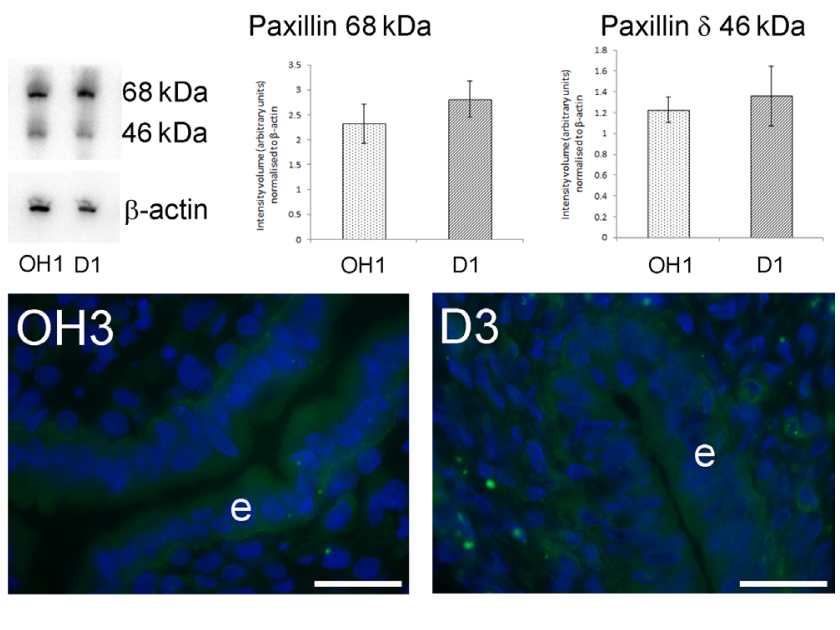

Paxillin $68 \mathrm{kDa}$

Paxillin $\delta 46 \mathrm{kDa}$

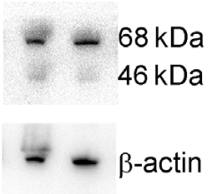

$\mathrm{OH} 3 \mathrm{D} 3$

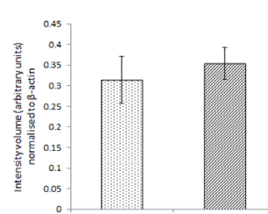

$\mathrm{OH} 3$

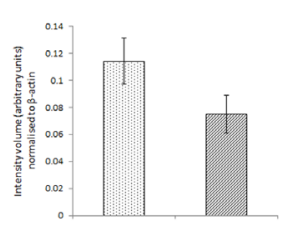

$\mathrm{OH} 3 \quad \mathrm{D} 3$
Figure 1 Immunofluorescence micrographs and western blotting analysis of paxillin on days 1 and 3 of normal and $\mathrm{OH}$ pregnancy. Paxillin staining (green) is seen as a basal band below uterine epithelial cells (e) on day 1 of normal pregnancy (D1, arrowhead). Similar basal staining is also seen below UECs (e) on day 1 after $\mathrm{OH}$ $(\mathrm{OH} 1$, arrowhead). Protein analysis from isolated UECs showed $68 \mathrm{kDa}$ (full-length paxillin) and $46 \mathrm{kDa}$ (paxillin $\delta$ ) bands. When normalised to $\beta$-actin, there is no difference in either $68 \mathrm{kDa}$ or $46 \mathrm{kDa}$ isoforms of paxillin between normal and $\mathrm{OH}$ pregnancy on day 1 . On day 3 of normal (D3) and $\mathrm{OH}$ pregnancy $(\mathrm{OH} 3)$, a small amount of cytoplasmic paxillin staining is seen in UECs (e). Western blotting analysis demonstrates full-length paxillin $(68 \mathrm{kDa})$ and a small amount of paxillin $\delta(46 \mathrm{kDa})$. However, there is no difference in amount of either protein in isolated UECs of normal compared with $\mathrm{OH}$ pregnancy. Green staining, paxillin; blue, nuclei; scale bar $=20 \mu \mathrm{m}$. 

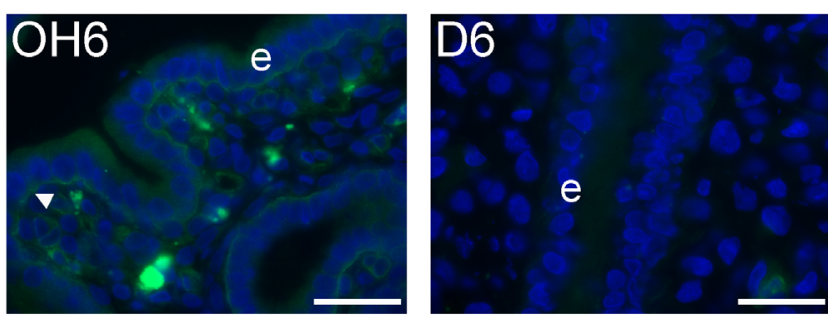

Paxillin 68 kDa
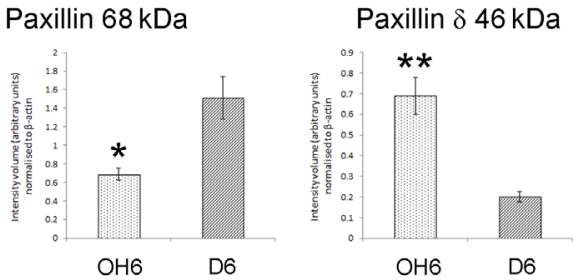

$\mathrm{OH} 6$

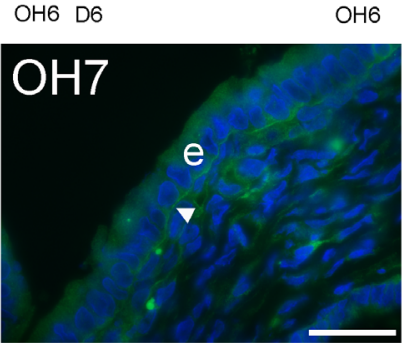

Paxillin $68 \mathrm{kDa}$

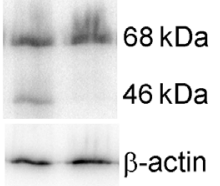

$\mathrm{OH} 7 \mathrm{D} 7$

$\mathrm{OH} 7$

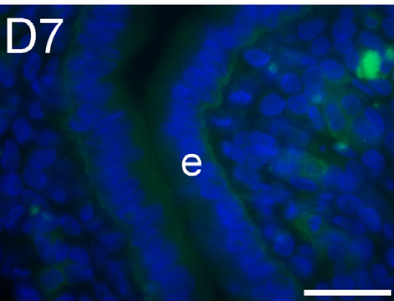

Paxillin $\delta 46 \mathrm{kDa}$

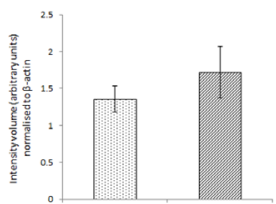

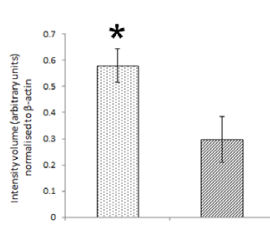

$\mathrm{OH} 7 \quad \mathrm{D} 7$
D7
Figure 2 Immunofluorescence micrographs and western blotting analysis of paxillin on days 6 and 7 of normal and $\mathrm{OH}$ pregnancy. Paxillin staining (green) is seen as a prominent basal band below UECs (e) on day 6 of $\mathrm{OH}$ pregnancy $(\mathrm{OH} 6$, arrowhead). There is no immunofluorescent staining on day 6 of pregnancy (D6). Western blotting analysis of isolated UECs from day 6 of normal and $\mathrm{OH}$ pregnancy showed full-length protein $(68 \mathrm{kDa})$ and paxillin $\delta$ isoform ( $46 \mathrm{kDa}$ ) bands. When normalised to $\beta$-actin, there was a significant reduction in full-length paxillin and an increase in paxillin $\delta$ in $\mathrm{OH}$ compared with normal pregnancy on day 6 . On day 7 of normal (D7) and $\mathrm{OH}$ pregnancy $(\mathrm{OH} 7)$, paxillin is seen as a basal band below the UECs (e, arrowhead). Protein analysis from isolated UECs showed $68 \mathrm{kDa}$ and $46 \mathrm{kDa}$ bands on day 7 of $\mathrm{OH}$ pregnancy and only the full-length protein from day 7 of pregnancy. When normalised to $\beta$-actin, there was no difference in $68 \mathrm{kDa}$ paxillin protein, but a significant increase in paxillin $\delta$ on day 7 in $\mathrm{OH}$ compared with normal pregnancy. Green staining, paxillin; blue, nuclei; scale bar $=20 \mu \mathrm{m} ;{ }^{*} P<0.05 ;{ }^{* *} P<0.001$.

This study used a rat ovarian hyperstimulation $(\mathrm{OH})$ model to investigate the effects of this protocol on ultrastructural FAs and related proteins in UECs at the time of receptivity. Previous studies using this $\mathrm{OH}$ model have shown a lack of implantation sites in treated animals, suggesting that this treatment interferes with normal uterine receptivity (Jovanovic \& Kramer 2010). Significant changes in uterine fluid and ion transport (Lindsay \& Murphy 2014) and change in important uterine adhesion molecules (Sendag et al. 2010, Biyiksiz et al. 2011) are also observed in $\mathrm{OH}$ pregnancy compared with normal pregnancy. There are, however, no data investigating ultrastructural or molecular changes of the basal plasma membrane of UECS at the time of implantation after $\mathrm{OH}$ compared with normal pregnancy.

\section{Materials and methods}

\section{Animals}

Adult female virgin Wistar rats were housed in a controlled environment with a 12-h light/darkness cycle and given food and water ad libitum. In one group of rats, vaginal smears were used to determine which animals were in pro-oestrus and these rats were mated overnight with a male of proven fertility. Mating was confirmed the following morning by the presence of sperm in a vaginal smear, this was designated as day 1 of pregnancy (D1).

A second group of animals were smeared daily until at least 2 continuous 4-day oestrous cycles were noted. At noon on the day of mid-dioestrus, an intraperitoneal injection of $20 \mathrm{IU}$ of serum gonadotropin (PMSG; Folligon; Intervet Australia, Vic, Australia) was delivered, followed $24 \mathrm{~h}$ later by an intraperitoneal injection of $20 \mathrm{IU}$ of human chorionic gonadotropin (hCG; Chorulon; Intervet, Australia). These ovarian hyperstimulated female rats were then mated overnight and the presence of sperm in the vaginal smear the following morning confirmed pregnancy, this was designated as day 1 of ovarian hyperstimulated pregnancy (OHD1).

Five animals per group (normal pregnancy D1, 3, 6 and 7; $\mathrm{OH}$ pregnancy OHD1, 3, 6 and 7) were killed with an intraperitoneal injection of sodium pentobarbitone (Troy Laboratories, Australia) and uterine tissue removed and processed as described below. All animal procedures were approved by the University of Sydney Animal Ethics Committee.

\section{Immunofluorescence microscopy}

Uterine horns randomly selected for light microscopy were immediately placed in cold $0.1 \mathrm{M}$ phosphate buffer $(\mathrm{pH} 7.4$ ) and cut into $5 \mathrm{~mm}$ pieces. Uterine pieces were covered with OCT (Tissue Tek, USA) and frozen in supercooled isopentane before being stored in liquid nitrogen until use. Sections, $8 \mu \mathrm{m}$ thick, were cut from at least 2 blocks per animal and placed on gelatin-chrome alum-coated slides. Sections were randomly allocated to each antibody or control IgGs. After fixing in $4 \%$ paraformaldehyde solution for $10 \mathrm{~min}$ at room temperature (RT) for paxillin, talin or Y397FAK, slides were washed with phosphate-buffered saline (PBS). Non-specific binding was blocked with PBS/1\% bovine serum albumin (BSA) for $30 \mathrm{~min}$ at RT. Primary antibodies were applied at a concentration of $14 \mu \mathrm{g} / \mathrm{mL}$ (Paxillin, Sigma-Aldrich), $16 \mu \mathrm{g} / \mathrm{mL}$ (Talin, SigmaAldrich), $20 \mu \mathrm{g} / \mathrm{mL}$ (Focal Adhesion Kinase, phosphor Y397, Abcam), $20 \mu \mathrm{g} / \mathrm{mL}$ (normal rabbit IgG, Sigma-Aldrich) or $16 \mu \mathrm{g} / \mathrm{mL}$ (normal mouse IgG, Sigma-Aldrich) overnight at 

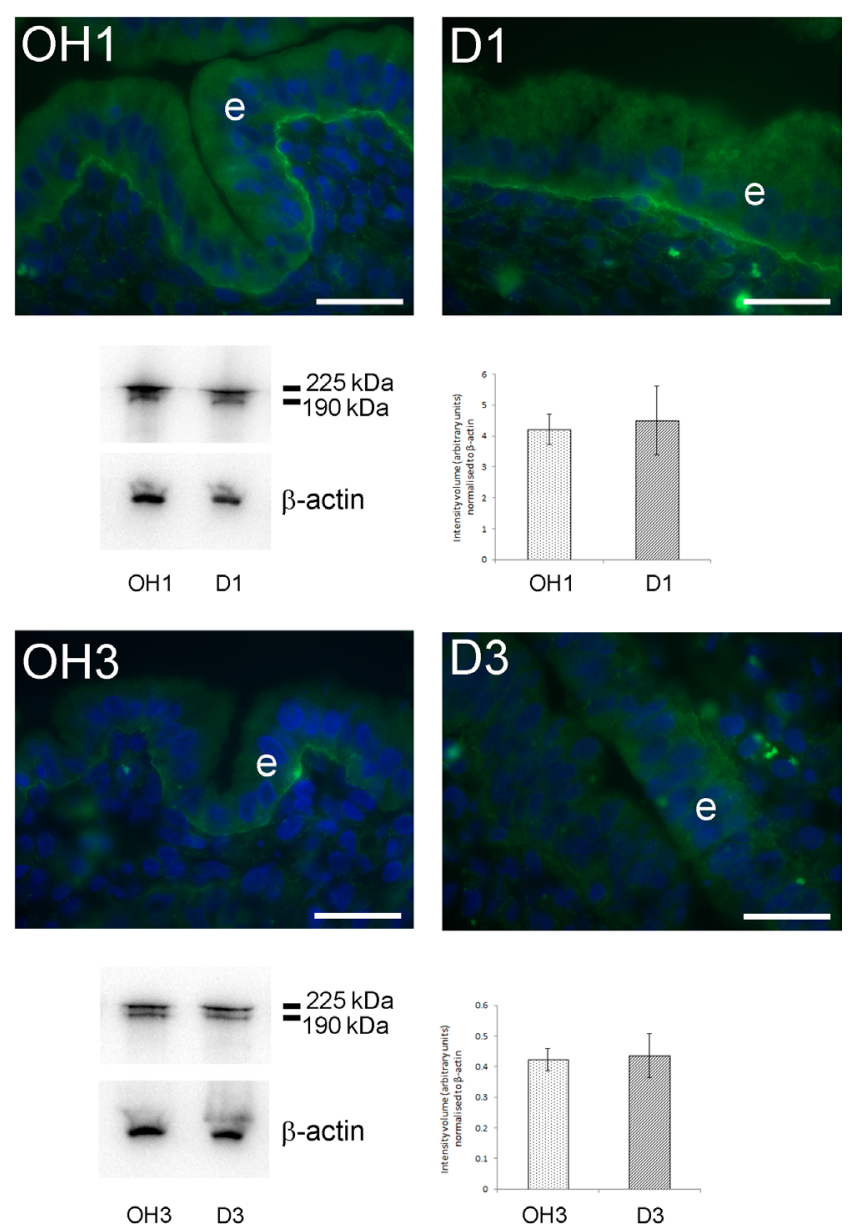

Figure 3 Immunofluorescence micrographs and Western blotting analysis of talin on days 1 and 3 of normal and $\mathrm{OH}$ pregnancy. Basal talin staining is seen in uterine epithelial cells (e) on day 1 of normal pregnancy (D1), day 1 of $\mathrm{OH}$ pregnancy $(\mathrm{OH} 1)$ and day 3 of $\mathrm{OH}$ pregnancy. Cytoplasmic talin staining is seen in UECs on day 3 of normal pregnancy (D3). Protein analysis from isolated UECs showed talin as $225 \mathrm{kDa}$ (full length) and $190 \mathrm{kDa}$ (proteolytically cleaved product) with no difference seen between $\mathrm{OH}$ and normal pregnancy on either days 1 or 3 . Green staining, talin; blue, nuclei; scale bar $=20 \mu \mathrm{m}$.

$4^{\circ} \mathrm{C}$. Sections were then washed in PBS and incubated in fluorescein isothiocyanate (FITC)-conjugated goat-anti-mouse IgG secondary antibodies for paxillin and talin $(1 \mu \mathrm{g} / \mathrm{mL}$, Jackson ImmunoResearch Laboratories) or FITC-conjugated goat-anti-rabbit IgG secondary antibodies for Y397FAK ( $3 \mu \mathrm{g} / \mathrm{mL}$, Jackson ImmunoResearch Laboratories) for $1 \mathrm{~h}$ at RT in the darkness to prevent quenching.

Sections randomly allocated for colocalisation experiments between integrin $\beta 1$ and talin were fixed in PFA for $10 \mathrm{~min}$, washed in PBS and blocked in PBS/1\% BSA for 30 min at RT before being incubated in integrin $\beta 1$ antibodies $(1 \mu \mathrm{g} / \mathrm{mL}$, Abcam) overnight at $4^{\circ} \mathrm{C}$. After washing in PBS, sections were incubated in FITC-conjugated goat-anti-rabbit IgG secondary antibodies for $2 \mathrm{~h}$ at RT, washed in PBS and incubated in $16 \mu \mathrm{g} /$ $\mathrm{mL}$ talin antibodies overnight at $4^{\circ} \mathrm{C}$.

All sections were washed in PBS, mounted with VECTASHIELD-containing DAPI (Vector, Burlingame, CA,
USA) coverslipped and observed immediately using the Zeiss Deconvolution Microscope (Carl Zeiss). Images were acquired using a Zeiss AxioCam HRM digital camera and Zen software (Carl Zeiss), and micrographs were produced using Photoshop software (Adobe Systems).

\section{Western blotting analysis}

Uterine horns randomly allocated for protein analysis were opened longitudinally to expose the luminal epithelium and gently washed with phosphate buffer. The epithelium was scraped using a scalpel blade and placed into $100 \mu \mathrm{L}$ of mammalian cell lysis buffer $(50 \mathrm{mM}$ Tris-HCl, $1 \mathrm{mM}$ EDTA, $150 \mathrm{mM}$ sodium chloride, $0.1 \%$ sodium dodecyl sulphate (SDS), $0.5 \%$ deoxycholic acid sodium salt solution and 1\% IGEPAL; Sigma)-containing 10\% phosphatase inhibitor cocktail (PhosSTOP, Roche, USA) and 1\% protease inhibitor cocktail (Sigma). The cell/lysis buffer solution was stored on
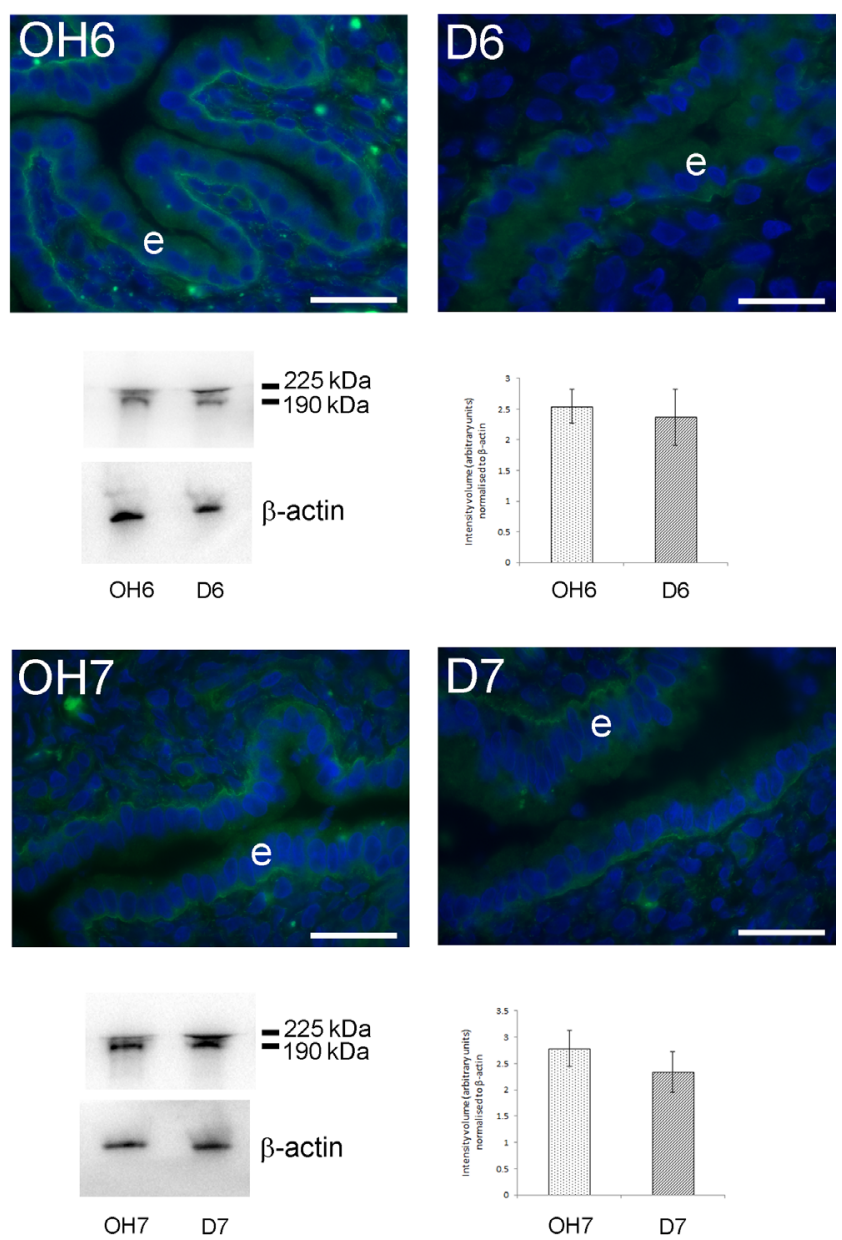

Figure 4 Immunofluorescence micrographs and Western blotting analysis of talin on days 6 and 7 of normal and $\mathrm{OH}$ pregnancy. Basal talin staining is seen in uterine epithelial cells (e) on days 6 and 7 of normal and $\mathrm{OH}$ pregnancy. Protein analysis from isolated UECs showed talin as $225 \mathrm{kDa}$ (full-length) and $190 \mathrm{kDa}$ (proteolytically cleaved product) with no difference seen between $\mathrm{OH}$ and normal pregnancy on either days 6 or 7 . Green staining, talin; blue, nuclei; scale bar $=20 \mu \mathrm{m}$. 

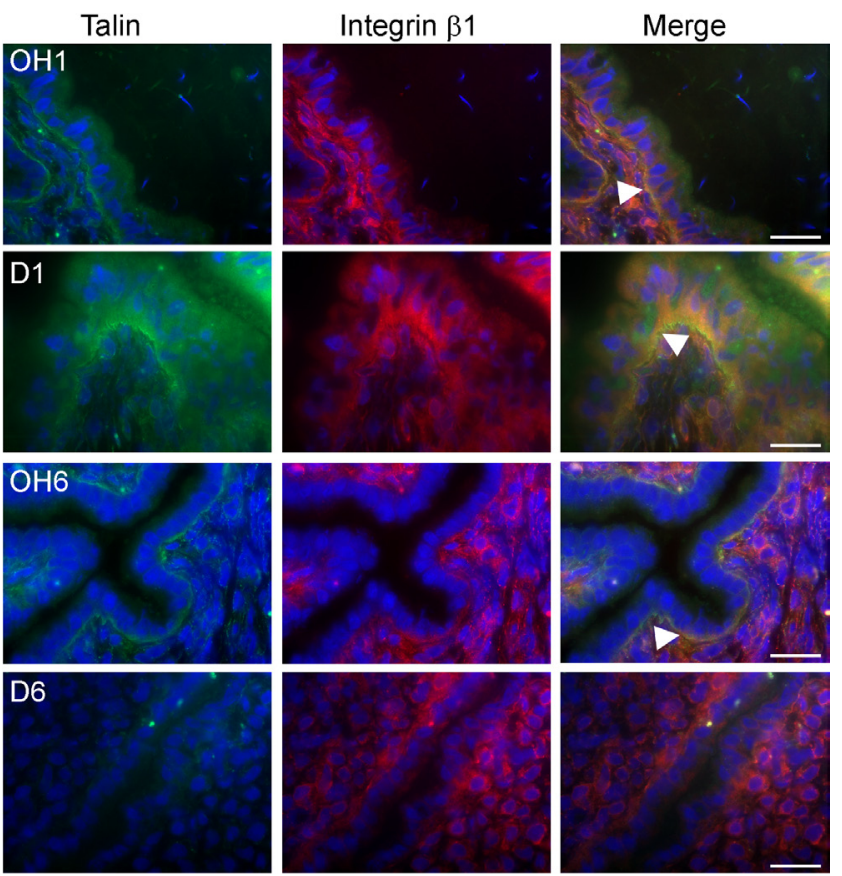

Figure 5 Immunofluorescence micrographs showing the location of talin (green), integrin $\beta 1$ (red) and the co-localisation (yellow) between these proteins on days 1 and 6 of normal pregnancy and after $\mathrm{OH}$. There is basal integrin $\beta 1$ staining of the luminal epithelial cells on day 1 of normal and $\mathrm{OH}$ pregnancy as well as on day 6 of $\mathrm{OH}$ pregnancy. There is no integrin $\beta 1$ staining of the luminal epithelial cells on day 6 of normal pregnancy. Talin and integrin $\beta 1$ co-localise (arrowhead) on days 1 and 6 of normal pregnancy and on day 6 after $\mathrm{OH}$. Green staining, talin; red, integrin $\beta 1$; blue, nuclei; scale bar $=20 \mu \mathrm{m}$.

ice for $10 \mathrm{~min}$ before being centrifuged to remove cellular debris, aliquoted and stored at $-80^{\circ} \mathrm{C}$ until use. Randomly selected regions of the remaining uterine horn were cut into $5 \mathrm{~mm}$ pieces, frozen and stored in liquid nitrogen as stated previously. Blocks were cut, stained with routine haematoxylin and eosin and observed to validate the removal of luminal epithelial cells only.

Protein concentration was determined using a Micro BCA Protein Assay Kit (Pierce Biotechnology, USA), and $20 \mu \mathrm{g}$ was loaded onto a $4-20 \%$ pre-cast gel (Bio-Rad) and electrophoresis was carried out according to the method of Laemmli (Laemmli 1970). Protein was transferred electrophoretically to polyvinylidene-fluoride microporous membranes (Millipore). Membranes were blocked with Tris-buffered saline (TBS)containing $0.05 \%$ Tween 20 (TBS-T) $/ 5 \%$ skim milk for $1 \mathrm{~h}$ at RT. Mouse-anti-paxillin $(7 \mu \mathrm{g} / \mathrm{mL})$, mouse-anti-talin $(1.1 \mu \mathrm{g} / \mathrm{mL})$, rabbit-anti-integrin $\beta 1(0.4 \mu \mathrm{g} / \mathrm{mL})$ and rabbit-anti-Y397FAK $(1 \mu \mathrm{g} / \mathrm{mL})$ antibodies were diluted with TBS-T/1\% skim milk and membranes were incubated overnight at $4{ }^{\circ} \mathrm{C}$. Membranes were washed in TBS-T and then incubated in $0.2 \mu \mathrm{g} / \mathrm{mL}$ HRPconjugated goat anti-mouse IgG (GE Healthcare) or $0.25 \mu \mathrm{g} / \mathrm{mL}$ horseradish peroxidase (HRP)-conjugated goat-anti-rabbit lgG (Dako) diluted in TBS-T/1\% skim milk for $2 \mathrm{~h}$ at RT. After the final wash in TBS-T, membranes were incubated in Immobilon Chemiluminescent Substrate (Millipore) before imaging with the Bio-Rad ChemiDoc MP Imaging System (Bio-Rad).
To reprobe the membranes for a protein loading control $(\beta$-actin), all membranes were washed and placed in stripping buffer (62.5 mM Tris- $\mathrm{HCl} \mathrm{pH}$ 6.7, 2\% SDS, $100 \mathrm{mM}$ $\beta$-mercaptoethanol) for $1 \mathrm{~h}$ at $60^{\circ} \mathrm{C}$. After washing, the membranes were again blocked in TBS-T/5\% skim milk and incubated in $0.4 \mu \mathrm{g} / \mathrm{mL}$ mouse-anti- $\beta$-actin antibodies diluted in TBS-T/ $\%$ skim milk overnight at $4^{\circ} \mathrm{C}$. Membranes were then washed and incubated in $0.2 \mu \mathrm{g} / \mathrm{mL}$ HRP-conjugated goat anti-mouse $\lg \mathrm{G}$ (GE Healthcare) diluted in TBS-T/1\% skim milk for $2 \mathrm{~h}$ at RT. The remaining washing and imaging was the same as described previously.

Densitometric analysis was performed by calculating the intensity volume using the Volume Analysis Tool (Bio-Rad imaging software, Bio-Rad) and normalised to $\beta$-actin. Statistical analysis was performed using GraphPad Prism software (GraphPad Software). Changes in the abundance of paxillin and talin between normal and $\mathrm{OH}$ pregnancy on each day of pregnancy studied were analysed using a two-tailed Student's $t$-test. Changes in abundance of integrin $\beta 1$ and Y397FAK were
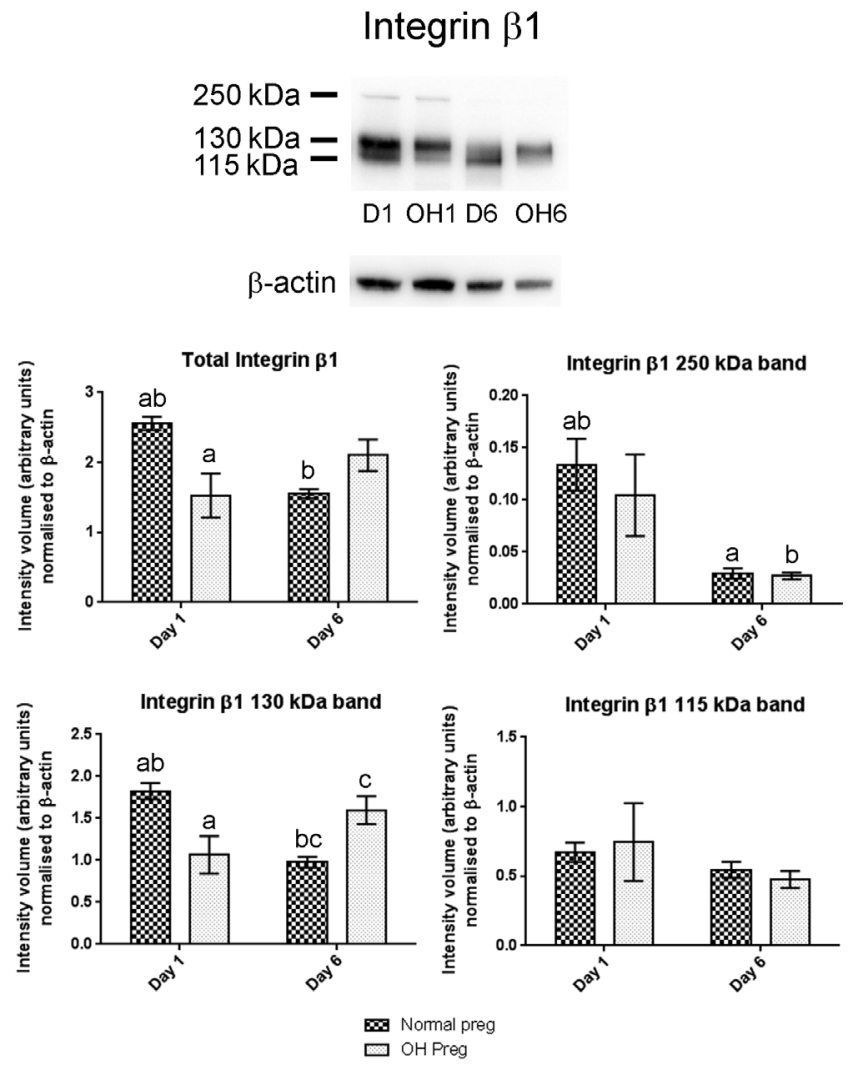

Figure 6 Protein analysis from isolated UECs showing integrin $\beta 1$ protein at 250, 130 and $115 \mathrm{kDa}$. Total integrin $\beta 1$ showed a significant decrease in the amount of total protein from day 1 of normal pregnancy compared with both day 1 of $\mathrm{OH}$ pregnancy and day 6 of normal pregnancy. There is a similar significant decrease in the $250 \mathrm{kDa}$ band in days 6 of normal and $\mathrm{OH}$ pregnancy compared with day 1 of normal pregnancy. The $130 \mathrm{kDa}$ band also shows a significant decrease on day 1 of $\mathrm{OH}$ pregnancy and day 6 of normal pregnancy compared with day 1 of normal pregnancy. There is also a significant increase in the $130 \mathrm{kDa}$ isoform on day $6 \mathrm{of} \mathrm{OH}$ compared with the same time during normal pregnancy. No significant differences were detected in relation to the $115 \mathrm{kDa}$ band. 

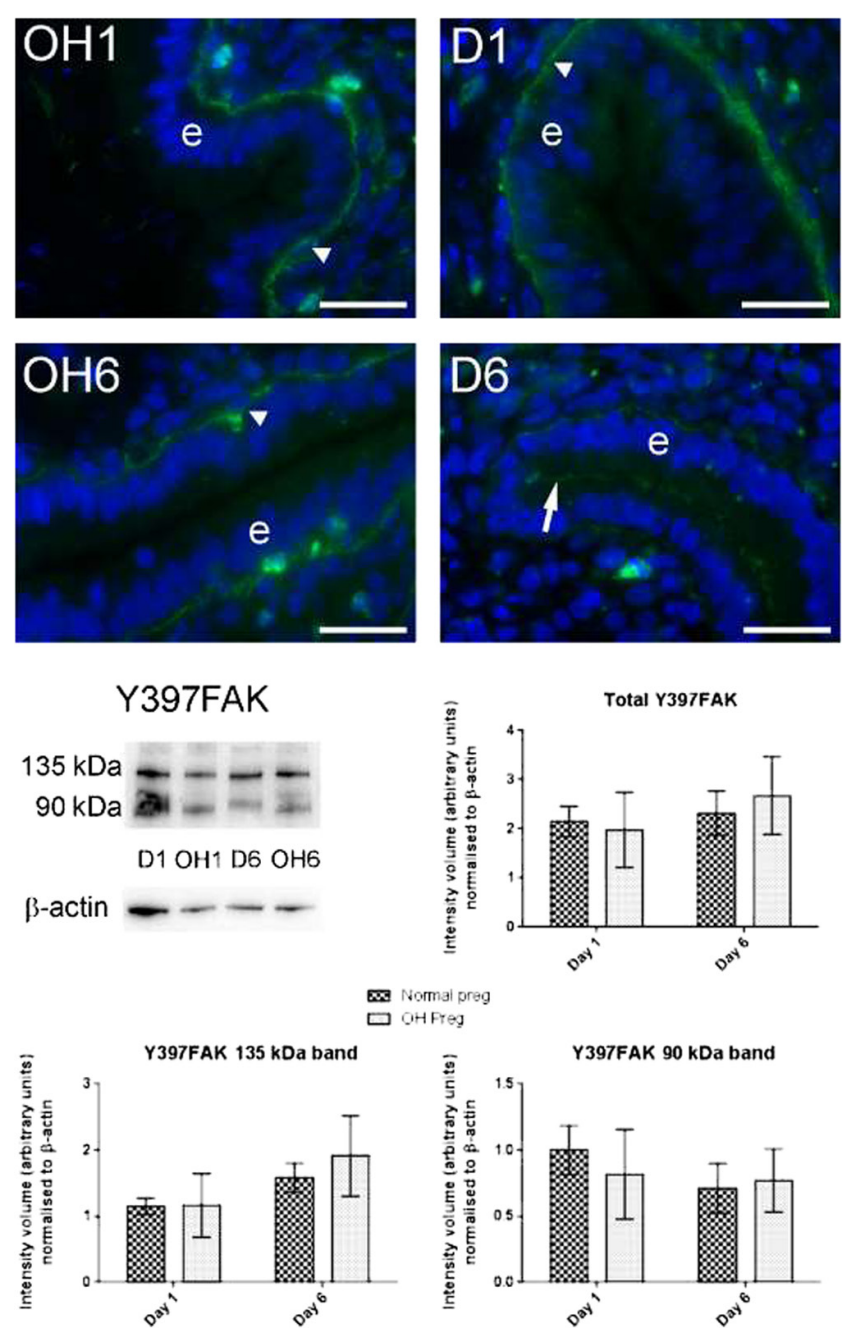

Figure 7 Immunofluorescence micrographs showing the location of phosphorylated FAK (Y397FAK) on days 1 and 6 of normal pregnancy and after $\mathrm{OH}$. Basal staining (arrowhead) is seen in the luminal epithelial cells (e) on days 1 of normal pregnancy as well as on days 1 and 6 of $\mathrm{OH}$ pregnancy. On day 6 of normal pregnancy, there is a small amount of apical immunofluorescent staining (arrow). Western blot analysis of isolated UECs shows Y397FAK as $135 \mathrm{kDa}$ and $90 \mathrm{kDa}$ bands with no significant difference between days or treatment groups (normal and $\mathrm{OH}$ pregnancy). Green staining, Y397FAK; blue, nuclei; scale bar $=20 \mu \mathrm{m}$.

analysed using two-way analysis of variance (ANOVA) with day of pregnancy (day 1 and day 6) and $\mathrm{OH}$ status (normal pregnancy and $\mathrm{OH}$ pregnancy) as factors. Tukey's post hoc test for multiple comparisons was then applied to determine which pairs of means were significantly different. Differences were determined to be statistically significant when $P<0.05$. Graphs were generated using GraphPad Prism software, and data are represented as mean +S.E.M.

\section{Transmission electron microscopy}

Uteri from 5 animals from both days 1 and 6 of normal and $\mathrm{OH}$ pregnancy were processed for TEM to show the ultrastructural changes. Tissue was cut into $5 \mathrm{~mm}$ pieces and immediately immersed in Karnovsky's fixative $(2.5 \%$ glutaraldehyde (ProSciTech, Australia), 2\% paraformaldehyde (ProSciTech) in 0.1 M Sorenson's phosphate buffer (PB, pH 7.2)) for $45 \mathrm{~min}$ at room temperature. After cutting into $0.5-1 \mathrm{~mm}$ slices, tissue was returned to fresh fixative for a further $45 \mathrm{~min}$. Tissue was then washed in $0.1 \mathrm{M} \mathrm{PB}$ and postfixed in $1 \%$ osmium tetroxide/ $0.8 \%$ potassium ferricyanide for $1 \mathrm{~h}$ followed by a milliQ water rinse and a 10-min $2 \%$ OsO4 incubation. After a further rinse in milliQ water, tissue was dehydrated in a graded series of ethanol, infiltrated and embedded in Spurrs Resin in BEEM capsules (ProSciTech, Australia). Two randomly selected blocks per animal were cut using a Leica Ultracut T ultramicrotome (Leica, Heerbrugg, Switzerland), and 65-70 nm sections were mounted onto 400-mesh copper grids. Sections were post-stained with a saturated solution of uranyl acetate in $50 \%$ ethanol for $45 \mathrm{~min}$, followed by Reynold's lead citrate for $10 \mathrm{~min}$. Sections were viewed with a Jeol 1011 transmission electron microscope (Jeol Ltd., Japan) at $80 \mathrm{kV}$. Images were captured with a Gatan SC200 Orius CCD Camera (Gatan Inc., USA).

\section{Results \\ Paxillin}

On day 1 of normal pregnancy and after $\mathrm{OH}$ treatment (Fig. 1), paxillin is seen in the basal plasma membrane of UECs. There is very little paxillin staining on day 3 of pregnancy with and without $\mathrm{OH}$ stimulation (Fig. 1). However, on day 6 of pregnancy, there is a difference in paxillin staining after $\mathrm{OH}$ treatment (Fig. 2). In normal pregnancy on day 6 , paxillin has disappeared from the basal membrane, whereas a distinct basal band is seen at this time after $\mathrm{OH}$. Protein from isolated UECs shows a significant decrease in full-size paxillin $(P=0.006)$ and a significant increase in paxillin $\delta$ in $\mathrm{OH}$ compared with those in normal pregnancy $(P=0.0009)$. On day 7 of pregnancy (Fig. 2), basal paxillin staining reappears in UECs during normal pregnancy and is also present on day 7 of $\mathrm{OH}$ pregnancy. Paxillin $\delta$ is significantly increased in $\mathrm{OH} 7$ compared with that in $\mathrm{D} 7(P=0.019)$.

\section{Talin}

Basal staining for talin is seen in all days of normal and $\mathrm{OH}$ pregnancy studied (Figs 3 and 4). Western blotting analysis of isolated uterine epithelial cells demonstrated $225 \mathrm{kDa}$ and $190 \mathrm{kDa}$ bands, the expected band size for talin. There was no significant change in total talin abundance in UECs between normal and $\mathrm{OH}$ pregnancy in any day studied (Figs 3 and 4).

\section{Integrin $\beta 1$}

Basal integrin $\beta 1$ staining is seen on day 1 of normal pregnancy and days 1 and 6 after $\mathrm{OH}$ (Fig. 5). On day 6 of normal pregnancy, there is integrin $\beta 1$ staining in the stroma but very little epithelial staining. 

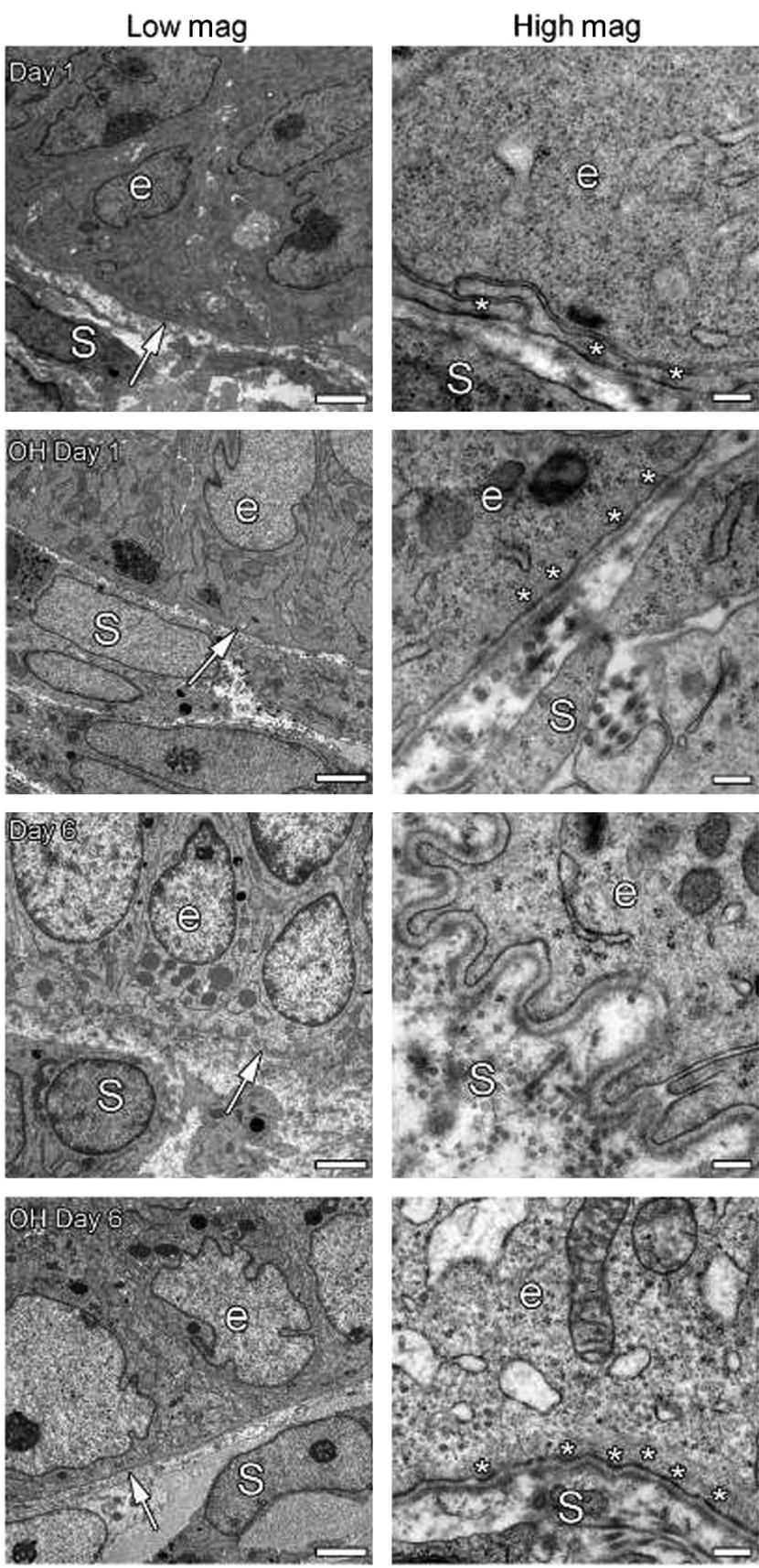

Figure 8 Electron micrographs of uterus showing the ultrastructural morphology of the basal region of luminal uterine epithelial cells (e) and underlying stroma (S) on days 1 and 6 of normal and $\mathrm{OH}$ pregnancy. On day 6 of normal pregnancy, the basal plasma membrane (arrow) is thickened and highly tortuous. There are no signs of basal plasma membrane thickenings. On day 1 of normal pregnancy and days 1 and 6 of $\mathrm{OH}$ pregnancy, the basal plasma membrane (arrow) is flattened. In higher magnification images, there are numerous basal plasma membrane thickenings, which are consistent with the morphological appearance of focal adhesions $(*)$ (Shion \& Murphy 1995). Scale bar in low mag images $=2 \mu \mathrm{m}$; high mag images $=200 \mathrm{~nm}$.
There is colocalisation of talin and integrin $\beta 1$ on day 1 of normal pregnancy as well as on days 1 and 6 after $\mathrm{OH}$ (Fig. 5). Western blot analysis of isolated luminal epithelial cells shows $250 \mathrm{kDa}, 130 \mathrm{kDa}$ and $115 \mathrm{kDa}$ bands (Fig. 6). There is a significant increase in total integrin $\beta 1$ protein on day 1 of normal pregnancy compared with day 1 after $\mathrm{OH}(P=0.0086)$ and day 6 of normal pregnancy $(P=0.0067)$. The larger band, $250 \mathrm{kDa}$, is significantly decreased on day 6 of normal $(P=0.0279)$ and $\mathrm{OH}$ pregnancy $(P=0.0243)$ compared with day 1 of normal pregnancy. There are also significant differences in the $130 \mathrm{kDa}$ band between days 1 of normal and after $\mathrm{OH}$ pregnancy $(P=0.011)$, between days 1 and 6 of normal pregnancy $(P=0.003)$ as well as a significant increase on day 6 of $\mathrm{OH}$ pregnancy compared with the same time during normal pregnancy $(P=0.0284)$. There were no significant differences between days and treatments in relation to the $115 \mathrm{kDa}$ band.

\section{Phosphorylated focal adhesion kinase (Y397FAK)}

Y397FAK is seen basally in uterine epithelial cells on days 1 and 6 of $\mathrm{OH}$ pregnancy and on day 1 of normal pregnancy. There is no basal staining on day 6 of normal pregnancy but some apical staining. Western blot analysis of isolated luminal epithelial cells reveals $135 \mathrm{kDa}$ and $90 \mathrm{kDa}$ bands, and there are no significant differences in total protein or the individual bands between treatment groups or days (Fig. 7).

\section{Ultrastructural morphology}

Electron micrographs show a flattened basal plasma membrane on day 1 of normal and $\mathrm{OH}$ pregnancy (Fig. 8, arrow) with numerous thickenings in the basal plasma membrane which are morphological focal adhesions (Fig. 8, asterisks). On day 6 of normal pregnancy, the basal plasma membrane is tortuous (Fig. 8, arrow) with a thick and prominent basal lamina. However, on day 6 after $\mathrm{OH}$, the basal plasma membrane is flattened (Fig. 8, arrow) with numerous morphological focal adhesions (Fig. 8, asterisks).
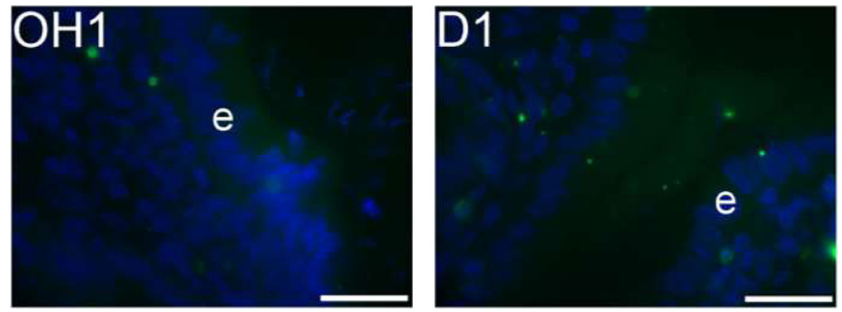

Figure 9 Immunofluorescent micrographs of rat uterus from day 1 of normal and $\mathrm{OH}$ pregnancy when incubated with normal mouse IgGs. No staining is seen, nuclei are counterstained blue. Scale bar $=20 \mu \mathrm{m}$. 


\section{Controls}

Non-immune controls were performed alongside all experimental runs and showed no staining. Normal and $\mathrm{OH}$ day 1 stained with mouse IgGs are shown as a representative example (Fig. 9).

\section{Discussion}

This is the first study to show an alteration in the morphological appearance of the basal plasma membrane, as well as the localisation and quantity of focal adhesion-associated proteins paxillin, talin, integrin $\beta 1$ and phosphorylated FAK (Y397FAK) in UECs during early pregnancy after ovarian hyperstimulation. The basal plasma membrane was found to be flattened and retains morphological focal adhesions at the time of implantation during ovarian hyperstimulated pregnancy. There was significantly less full-length paxillin and a greater abundance of paxillin $\delta$ at the time of implantation in $\mathrm{OH}$ compared with normal pregnancy, as well as retention of integrin $\beta 1$ and Y397FAK in the basal region of luminal uterine epithelial cells. Talin localisation and quantity, as well as the quantity of Y397FAK remained unchanged between days and $\mathrm{OH}$ treatment.

\section{Retention of a flattened basal plasma membrane at the time of implantation during ovarian hyperstimulated pregnancy}

During normal pregnancy in the rat at the time of implantation, the basal plasma membrane becomes highly tortuous and the basal lamina thickens (Shion \& Murphy 1995). There is also a loss of morphological focal adhesions at this time (Shion \& Murphy 1995). In contrast, this study found that during $\mathrm{OH}$ pregnancy, the basal plasma membrane remained flattened at the time of implantation, similar to the morphological appearance seen at the time of fertilisation (Shion \& Murphy 1995). Furthermore, at the time of implantation in $\mathrm{OH}$ rats, numerous morphological focal adhesions were seen. This suggests that the UECs are more adherent to the underlying stromal tissue at the time of implantation during $\mathrm{OH}$ pregnancy.

\section{Focal adhesion-associated proteins are still present at the time of implantation in $\mathrm{OH}$ pregnancy}

This study also demonstrated the presence of paxillin, talin, integrin $\beta 1$ and Y397FAK in the basal region of UECs at the time of fertilisation in $\mathrm{OH}$ and normal pregnancy, as well as at the time of implantation in $\mathrm{OH}$ pregnancy only. This demonstrates the presence of FA-associated proteins in the same subcellular location as the morphological focal adhesions during the time of implantation in $\mathrm{OH}$ pregnancy. Resolution differences between light and transmission electron microscopy would explain the appearance of an unbroken staining region of paxillin, talin, integrin $\beta 1$ or Y397FAK in the light microscope, whereas individual FA complexes are resolved using TEM.

The distinct basal localisation of paxillin seen in the immunofluorescent images on day 6 of $\mathrm{OH}$ pregnancy most likely represents the large pool of the paxillin $\delta$ isoform as evidenced by the significantly greater amount of this isoform compared with the same time during normal pregnancy. The larger abundance of full-length paxillin seen at the time of implantation in normal pregnancy compared with $\mathrm{OH}$ pregnancy seen in the Western blot data may constitute a diffuse cytoplasmic dispersion of this protein, which is unable to be detected via immunofluorescent localisation.

This alteration in the quantity of paxillin at the time of implantation between $\mathrm{OH}$ and normal pregnancy with less of the full-length paxillin and more paxillin $\delta$, further demonstrates the morphological appearance and functional role of focal adhesions at this time.

\section{Increased basal adhesion of UECs at the time of implantation in $\mathrm{OH}$ pregnancy}

Paxillin $\delta$, a $46 \mathrm{kDa}$ internal translation product of paxillin (Brown \& Turner 2004, Tumbarello et al. 2005), increases at the time of implantation in $\mathrm{OH}$ compared with normal pregnancy. However, at the time of implantation during normal pregnancy, there is a significant decrease in paxillin $\delta$ compared with the time of fertilisation (Kaneko et al. 2008). As paxillin $\delta$ is associated with a less-motile phenotype (Sorenson \& Sheibani 1999, Tumbarello et al. 2005), this suggests that the UECs are more firmly adherent to the underlying connective tissue at the time of implantation in $\mathrm{OH}$ compared with normal pregnancy.

Furthermore, this study found the colocalisation between integrin $\beta 1$ and talin at the time of implantation during $\mathrm{OH}$ pregnancy supporting the idea of a functional FA complex and increased basal adhesion at this time.

Results from this study suggest an increased adhesiveness between the UECs and underlying connective tissue at the time of implantation in $\mathrm{OH}$ pregnancy compared with the same time of normal pregnancy. The ability of the UECs to become less adherent at the time of implantation is essential for the removal of the epithelial layer to allow the blastocyst to invade into the underlying stroma and the subsequent establishment of a placenta. The retention of focal adhesions during $\mathrm{OH}$ pregnancy indicates that adherent UECs may provide more of a barrier to implantation of the blastocyst.

\section{Alterations in integrins during $\mathrm{OH}$ pregnancy}

Integrin $\beta 1$ was found in the basal region of uterine epithelial cells at the time of implantation during 
$\mathrm{OH}$ pregnancy. The loss of integrin $\beta 1$ at the time of implantation during normal pregnancy and a decrease in the $130 \mathrm{kDa}$ band (expected band size) compared with day 1 of pregnancy confirms results from a previous study (Kaneko et al. 2011). The $250 \mathrm{kDa}$ dimer was found to significantly decrease on day 6 of normal and $\mathrm{OH}$ pregnancy compared with day 1 of normal pregnancy. The appearance of integrins as a dimer suggests an interaction within a FA complex where integrin $\alpha$ and $\beta$ usually tightly interact (Takagi et al. 2001, Mouguelar et al. 2011). There was also an increase in the $130 \mathrm{kDa}$ band, the expected band size, at the time of implantation in $\mathrm{OH}$ pregnancy compared with normal pregnancy. This increase in monomeric integrin $\beta 1$ suggests an intact FA complex that could prevent the disassembly of Fas, which is an important process in allowing the uterine epithelial cells to become less adherent to the underlying basal lamina (Kaneko et al. 2008).

Phosphorylated FAK (Y397FAK) was found for the first time to be basally located within uterine epithelial cells at the time of fertilisation during normal and $\mathrm{OH}$ pregnancy as well as at the time of implantation during $\mathrm{OH}$ pregnancy. At the time of implantation during normal pregnancy, Y397FAK was only found apically where it may play a role in regulating integrin $\beta 3$ binding between the apical surface of uterine epithelial cells and trophoblastic cells of the blastocyst (Kaneko et al. 2011). Previous studies have shown a decrease in integrin $\beta 3$ localisation within uterine epithelial cells at the time of implantation during $\mathrm{COH}$ (Biyiksiz et al. 2011). Although there was no change in Y397FAK protein quantity between $\mathrm{OH}$ and normal pregnancy at the time of implantation, there was a very different localisation. During $\mathrm{OH}$ pregnancy, Y397FAK remained localised to the basal region of uterine epithelial cells where it is proposed to be associated with the FA complex. This is also the time when integrin $\beta 1$ and talin are colocalised, suggesting a stable FA complex.

\section{Ovarian hormones and retention of focal adhesions at the time of implantation in $\mathrm{OH}$ pregnancy}

Previous studies using this rat $\mathrm{OH}$ model have found an alteration in ovarian hormones oestradiol and progesterone in $\mathrm{OH}$ compared with that in normal pregnancy (Jovanovic \& Kramer 2010) with an increase in the progesterone:oestradiol ratio observed at implantation. This decrease in oestradiol and increase in progesterone seen at this time does not fully explain the distributional and quantitative changes observed in the focal adhesion-associated proteins seen in this study. The flattening of the basal plasma membrane as well as the increase in paxillin $\delta$ seen at the time of implantation in $\mathrm{OH}$ compared with normal pregnancy is also observed in ovariectomised rats treated with 3 days of oestradiol treatment, but not in animals treated with progesterone alone or in combination with oestradiol
(Shion \& Murphy 1995, Kaneko et al. 2009). Similarly, the basal localisation of integrin $\beta 1$ and total FAK was also seen in oestradiol-treated ovariectomised animals (Kaneko et al. 2011, 2012). Thus, although there is an alteration in ovarian hormones during $\mathrm{OH}$ pregnancy, these are not sufficient to explain the changes in key focal adhesion molecules seen in this study at the time of implantation in $\mathrm{OH}$ pregnancy.

The use of animal models of ovarian hyperstimulated pregnancy has already demonstrated disturbances in uterine fluid transport mechanisms (Lindsay \& Murphy 2014), alterations in adhesion molecules (Sendag et al. 2010, Biyiksiz et al. 2011) and now changes in the components of key basal structural complexes, which indicate that UECs may be less easily removed by an implanting blastocyst. A picture of a mechanistic change in UECs in response to $\mathrm{OH}$ therapy is becoming evident, and this may have wider implications for human IVF cycles. More studies are required to investigate if similar morphological changes occur in response to $\mathrm{COH}$ in humans.

\section{Declaration of interest}

The authors declare that there is no conflict of interest that could be perceived as prejudicing the impartiality of the research reported.

\section{Funding}

Financial support was provided by the Australian Research Council, The Ann Macintosh Foundation of the Discipline of Anatomy \& Histology and the Murphy Laboratory.

\section{Acknowledgements}

The authors acknowledge the facilities, and the scientific and technical assistance, of the Australian Microscopy and Microanalysis Research Facility at the Australian Centre for Microscopy and Microanalysis, The University of Sydney. The authors also acknowledge Dr Louise Cole (Core Facilities Manager, Bosch Institute Advanced Microscopy Facility, The University of Sydney) for her assistance with the microscopy imaging and Dr Donna Lai (Molecular Biology Officer, Bosch Institute Molecular Biology Facility, The University of Sydney) for her support with Western blotting.

\section{References}

Biyiksiz PC, Filiz S \& Vural B 2011 Is sildenafil citrate affect endometrial receptivity? An immunohistochemical study. Gynecological Endocrinology 27 767-774. (doi:10.3109/09513590.2010.540601)

Bowen JA, Bazer FW \& Burghardt RC 1996 Spatial and temporal analyses of integrin and Muc-1 expression in porcine uterine epithelium and trophectoderm in vivo. Biology of Reproduction 55 1098-1106. (doi:10.1095/biolreprod55.5.1098)

Brami-Cherrier K, Gervasi N, Arsenieva D, Walkiewicz K, Boutterin MC, Ortega A, Leonard PG, Seantier B, Gasmi L, Bouceba T et al. 2014 FAK 
dimerization controls its kinase-dependent functions at focal adhesions. EMBO Journal 33 356-370. (doi:10.1002/embj.201386399)

Brown MC \& Turner CE 2004 Paxillin: adapting to change. Physiological Reviews 84 1315-1339. (doi:10.1152/physrev.00002.2004)

Calderwood D 2004 Talin controls integrin activation. Biochemical Society Transactions 32 434-437. (doi:10.1042/bst0320434)

Calderwood DA, Zent R, Grant R, Rees DJG, Hynes RO \& Ginsberg MH 1999 The talin head domain binds to integrin $\beta$ subunit cytoplasmic tails and regulates integrin activation. Journal of Biological Chemistry 274 28071-28074. (doi:10.1074/jbc.274.40.28071)

Cary LA \& Guan J-L 1999 Focal adhesion kinase in integrin-mediated signaling. Frontiers in Bioscience 4 D102-D113. (doi:10.2741/Cary)

Chan PY, Kanner SB, Whitney G \& Aruffo A 1994 A transmembraneanchored chimeric focal adhesion kinase is constitutively activated and phosphorylated at tyrosine residues identical to Pp125(Fak). Journal of Biological Chemistry $26920567-20574$.

Check JH, Hourani C, Choe JK, Callan C \& Adelson HG 1994 Pregnancy rates in donors versus recipients according to the serum progesterone level at the time of human chorionic-gonadotropin in a shared oocyte program. Fertility and Sterility 61 262-264. (doi:10.1016/S00150282(16)56514-5)

Check JH, Wilson C, Choe JK, Amui J \& Brasile D 2010 Evidence that high serum progesterone $(\mathrm{P})$ levels on day of human chorionic gonadotropin (hCG) injection have no adverse effect on the embryo itself as determined by pregnancy outcome following embryo transfer using donated eggs. Clinical and Experimental Obstetrics \& Gynecology 37 179-180.

Critchley DR 2000 Focal adhesions-the cytoskeletal connection. Current Opinion in Cell Biology 12 133-139. (doi:10.1016/S09550674(99)00067-8)

Critchley DR 2009 Biochemical and structural properties of the integrinassociated cytoskeletal protein talin. Annual Review of Biophysics 38 235-254. (doi:10.1146/annurev.biophys.050708.133744)

Eide BL, Turck CW \& Escobedo JA 1995 Identification of Tyr-397 as the primary site of tyrosine phosphorylation and $\mathrm{Pp} 60$ (Src) association in the focal adhesion kinase, Pp125(Fak). Molecular and Cellular Biology 15 2819-2827. (doi:10.1128/MCB.15.5.2819)

Fazleabas AT, Bell SC, Fleming S, Sun J \& Lessey BA 1997 Distribution of integrins and the extracellular matrix proteins in the baboon endometrium during the menstrual cycle and early pregnancy. Biology of Reproduction 56 348-356. (doi:10.1095/biolreprod56.2.348)

Hauck CR, Hsia DA \& Schlaepfer DD 2002 The focal adhesion kinase-a regulator of cell migration and invasion. IUBMB Life 53 115-119. (doi:10.1080/15216540211470)

Ilić D, Genbačev O, Jin F, Caceres E, Almeida EA, Bellingard-Dubouchaud V, Schaefer EM, Damsky CH \& Fisher SJ 2001 Plasma membrane-associated pY397FAK is a marker of cytotrophoblast invasion in vivo and in vitro. American Journal of Pathology 159 93-108. (doi: 10.1016/s0002-9440(10)61677-x)

Jovanovic A \& Kramer B 2010 The effect of hyperstimulation on transforming growth factor beta(1) and beta(2) in the rat uterus: possible consequences for embryo implantation. Fertility \& Sterility 93 1509-1517. (doi: 10.1016/j.fertnstert.2008.12.092)

Kaneko Y, Lindsay LA \& Murphy CR 2008 Focal adhesions disassemble during early pregnancy in rat uterine epithelial cells. Reproduction, Fertility and Development 20 892-899. (doi:10.1071/RD08148)

Kaneko Y, Lecce L \& Murphy CR 2009 Ovarian hormones regulate expression of the focal adhesion proteins, talin and paxillin, in rat uterine luminal but not glandular epithelial cells. Histochemistry and Cell Biology 132 613-622. (doi:10.1007/s00418-009-0641-x)

Kaneko Y, Lecce L, Day ML \& Murphy CR 2011 beta(1) and beta(3) integrins disassemble from basal focal adhesions and beta(3) integrin is later localised to the apical plasma membrane of rat uterine luminal epithelial cells at the time of implantation. Reproduction, Fertility and Development 23 481-495. (doi:10.1071/RD10211)

Kaneko Y, Lecce L, Day ML \& Murphy CR 2012 Focal adhesion kinase localizes to sites of cell-to-cell contact in vivo and increases apically in rat uterine luminal epithelium and the blastocyst at the time of implantation. Journal of Morphology 273 639-650. (doi:10.1002/jmor.20010)

Katz BZ, Romer L, Miyamoto S, Volberg T, Matsumoto K, Cukierman E, Geiger B \& Yamada KM 2003 Targeting membrane-localized focal adhesion kinase to focal adhesions - roles of tyrosine phosphorylation and Src family kinases. Journal of Biological Chemistry 278 29115-29120. (doi:10.1074/jbc.M212396200)
Kuo J-C, Han X, Hsiao C-T, Yates III JR \& Waterman CM 2011 Analysis of the myosin-II-responsive focal adhesion proteome reveals a role for [beta]-Pix in negative regulation of focal adhesion maturation. Nature Cell Biology 13 383-393. (doi:10.1038/ncb2216)

Laemmli UK 1970 Cleavage of structural proteins during the assembly of the head of bacteriophage T4. Nature 227 680-685. (doi:10.1038/227680a0)

Lessey BA 1997 Integrins and the endometrium: new markers of uterine receptivity. Annals of the New York Academy of Sciences 828 111-122. (doi:10.1111/j.1749-6632.1997.tb48529.x)

Li Y, Reznichenko M, Tribe RM, Hess PE, Taggart M, Kim H, DeGnore JP, Gangopadhyay S \& Morgan KG 2009 Stretch activates human myometrium via ERK, caldesmon and focal adhesion signaling. PLOS ONE 4 e7489. (doi:10.1371/journal.pone.0007489)

Li Y, Sun X \& Dey SK 2015 Entosis allows timely elimination of the luminal epithelial barrier for embryo implantation. Cell Reports 11 358-365. (doi:10.1016/j.celrep.2015.03.035)

Lindsay LA \& Murphy CR 2014 Ovarian hyperstimulation affects fluid transporters in the uterus: a potential mechanism in uterine receptivity. Reproduction, Fertility and Development 26 982-990. (doi:10.1071/ RD12396)

Mazaki Y, Hashimoto S \& Sabe H 1997 Monocyte cells and cancer cells express novel paxillin isoforms with different binding properties to focal adhesion proteins. Journal of Biological Chemistry 272 7437-7444. (doi:10.1074/jbc.272.11.7437)

Mouguelar VS, Cabada MO \& Coux G 2011 The integrin-binding motif RGDS induces protein tyrosine phosphorylation without activation in Bufo arenarum (Amphibia) oocytes. Reproduction 141 581-593. (doi:10.1530/REP-10-0411)

Nayal A, Webb DJ \& Horwitz AF 2004 Talin: an emerging focal point of adhesion dynamics. Current Opinion in Cell Biology 16 94-98. (doi:10.1016/j.ceb.2003.11.007)

Orazizadeh M, Rashidi I, Saremi J \& Latifi M 2009 Focal adhesion kinase (FAK) involvement in human endometrial remodeling during the menstrual cycle. Iranian Biomedical Journal 1395.

Parr EL, Tung HN \& Parr MB 1987 Apoptosis as the mode of uterine epithelial-cell death during embryo implantation in mice and rats. Biology of Reproduction 36 211-225. (doi:10.1095/biolreprod36.1.211)

Paulson RJ, Sauer MV \& Lobo RA 1990 Embryo implantation after human in vitro fertilization: importance of endometrial receptivity. Fertility \& Sterility 53 870-874. (doi: 10.1016/s0015-0282(16)53524-9)

Schaller MD 2001 Paxillin: a focal adhesion-associated adaptor protein. Oncogene 20 6459-6472. (doi:10.1038/sj.onc.1204786)

Schaller MD, Hildebrand JD, Shannon JD, Fox JW, Vines RR \& Parsons JT 1994 Autophosphorylation of the focal adhesion kinase, Pp125(Fak), directs Sh2 dependent binding of Pp60(Src). Molecular and Cellular Biology 14 1680-1688. (doi:10.1128/MCB.14.3.1680)

Schlaepfer DD, Hauck CR \& Sieg DJ 1999 Signaling through focal adhesion kinase. Progress in Biophysics and Molecular Biology 71 435-478. (doi:10.1016/S0079-6107(98)00052-2)

Schlafke S \& Enders AC 1975 Cellular basis of interaction between trophoblast and uterus at implantation. Biology of Reproduction 12 41-65. (doi:10.1095/biolreprod12.1.41)

Sendag F, Akdogan A, Ozbilgin K, Giray G \& Oztekin K 2010 Effect of ovarian stimulation with human menopausal gonadotropin and recombinant follicle stimulating hormone on the expression of integrins alpha(3), beta(1) in the rat endometrium during the implantation period. European Journal of Obstetrics \& Gynecology and Reproductive Biology 150 57-60. (doi: 10.1016/j.ejogrb.2010.02.009)

Shapiro BS, Daneshmand ST, Garner FC, Aguirre M \& Hudson C 2014 Clinical rationale for cryopreservation of entire embryo cohorts in lieu of fresh transfer. Fertility and Sterility 102 3-9. (doi:10.1016/ j.fertnstert.2014.04.018)

Shapiro BS, Daneshmand ST, Garner FC, Aguirre M, Hudson C \& Thomas S 2011 Evidence of impaired endometrial receptivity after ovarian stimulation for in vitro fertilization: a prospective randomized trial comparing fresh and frozen-thawed embryo transfer in normal responders. Fertility and Sterility 96 344-348. (doi:10.1016/ j.fertnstert.2011.05.050)

Shion Y \& Murphy C 1995 The basal plasma membrane and lamina densa of uterine epithelial cells are both altered during early pregnancy and by ovarian hormones in the rat. European Journal of Morphology 33 257-264.

Sorenson CM \& Sheibani N 1999 Focal adhesion kinase, paxillin, and BCl-2: analysis of expression, phosphorylation, and association during 
morphogenesis. Developmental Dynamics 215 371-382. (doi:10.1002/ (SICl)1097-0177(199908)215:4<371::AID-AJA8>3.0.CO;2-H)

Srinivasan KR, Blesson CS, Fatima I, Kitchlu S, Jain SK, Mehrotra PK \& Dwivedi A 2009 Expression of alphaVbeta3 integrin in rat endometrial epithelial cells and its functional role during implantation. General and Comparative Endocrinology 160 124-133. (doi:10.1016/ j.ygcen.2008.10.021)

Tadokoro S, Shattil SJ, Eto K, Tai V, Liddington RC, de Pereda JM, Ginsberg MH \& Calderwood DA 2003 Talin binding to integrin beta tails: a final common step in integrin activation. Science 302 103-106. (doi:10.1126/science.1086652)

Takagi J, Erickson HP \& Springer TA 2001 C-terminal opening mimics 'inside-out'activation of integrin $\alpha 5 \beta 1$. Nature Structural \& Molecular Biology 8 412-416.

Tumbarello DA, Brown MC, Hetey SE \& Turner CE 2005 Regulation of paxillin family members during epithelial-mesenchymal transformation: a putative role for paxillin $\delta$. Journal of Cell Science 118 4849-4863. (doi:10.1242/jcs.02615)

Turner CE 2000 Paxillin and focal adhesion signalling. Nature Cell Biology 2 E231-E236. (doi:10.1038/35046659)
Turner CE, Glenney JR \& Burridge K 1990 Paxillin: a new vinculinbinding protein present in focal adhesions. Journal of Cell Biology $\mathbf{1 1 1}$ 1059-1068. (doi:10.1083/jcb.111.3.1059)

Vuori K 1998 Integrin signaling: tyrosine phosphorylation events in focal adhesions. Journal of Membrane Biology 165 191-199. (doi:10.1007/ s002329900433)

Yamada KM \& Geiger B 1997 Molecular interactions in cell adhesion complexes. Current Opinion in Cell Biology 9 76-85. (doi:10.1016/ S0955-0674(97)80155-X)

Zaidel-Bar R, Itzkovitz S, Ma'ayan A, Iyengar R \& Geiger B 2007 Functional atlas of the integrin adhesome. Nature Cell Biology $\mathbf{9}$ 858-867. (doi:10.1038/ncb0807-858)

Received 20 June 2016

First decision 3 August 2016

Revised manuscript received 30 August 2016

Accepted 19 September 2016 